\title{
Abnormal Return, Market Reaction around Rating Announcement in Tunisian Stock Market
}

\author{
Wissem Daadaa ${ }^{1}$ \\ ${ }^{1}$ Laboratory of Economics and Finance Engineering LIFE, University of El Manar, FSEG Tunis, Tunisia \\ Correspondence: Wissem Daadaa, Laboratory of Economics and Finance Engineering LIFE, University of El \\ Manar, FSEG Tunis, Tunisia. E-mail: Wissem.daadaa@yahoo.fr
}

Received: July 21, 2015

Accepted: May 27, 2016

Online Published: June 25, 2016

doi:10.5539/ijef.v8n7p322

URL: http://dx.doi.org/10.5539/ijef.v8n7p322

\begin{abstract}
This paper tests the market reaction and the stock price change around rating announcements in Tunisian stock exchange using the event study methodology. We examine the impact of the change rating announcement on stock return firms from 2006 to 2010 . The results show that only the negative rating with downgrades note which is associated to negative abnormal return. The market does not seem to be interested upgrades rating on the Tunisian market. The negative reaction of the market can be explained by leverage change, Book to Market ratio and the level of the rating fall.
\end{abstract}

Keywords: rating, abnormal return, event study

\section{Introduction}

The number of rating agencies increases in this decade; we estimate more than 100 rating agencies in the world. The role assumed by theses agencies become more and more important and theirs announcements constitutes an event that affect the market reaction and stock firm return. Analyzing the effect of rating agencies decision is an important event, essentially, to small markets. The rating announcement has solicited a reach literature in events studies literatures. The rating agencies evaluate firms using different criteria and standard processes, and thus theirs decisions can transmit a signal to the market. Lee-Hsien Pana et al. (2015) presents different indicators criteria used to evaluate firms: corporate transparency, firm performance and classify firms in five classes: the highest corporate transparency is notified to an A++ rating, firm with the lowest corporate transparency is Crating. The five classes of rating is: (1) compliance with the mandatory information disclosures, (2) timeliness of information reporting, (3) disclosure of financial forecast, (4) disclosure of annual report, and (5) disclosure of corporate website. Before notification announcements, rating agencies collect financial information from public and private sources.

The change notification announcement transmits new information to the market; as a result, every degradation, downgrades and changes should have a negative effect on stock prices. Similarly, put under positive surveillance, upward revisions and positive changes should result improvement value. Thus, the impact of the company's notification variation on the share stock price can be explained by the effect of the new information announced to the market, any change in the rating is likely to affect the financial capital cost, their profitability, and consequently their market value. Similarly, the company's notification change can influence firm's growth and their future vale. Researches in the subject of rating have increasingly in vogue, but, the majority of these studies were conducted in developed markets. Rare papers that have tested market reaction in emerging market. Their reaction following rating announcements was always ignored, it must not also forget that the culture of using rating agencies is not developed enough and so this type of work allows, among others, to break the reluctance to seek rating.

The Tunisian capital market offers an interesting area to test the rating agencies' decision. We test the market reaction to rating agency announcements by measuring stock abnormal return. The market characteristics and the lack of prior studies motivate this research and form the basis for its contribution to the research literature. This paper evaluates the information value of Tunisian stock market after rating agencies announcements. The database of this study includes rating announcements for the period 1 January 2000 to 31 December 2010, of Tunisian rating agency. We use event study methodology to test stock abnormal returns around announcement date. 
After a literature review of the main works that have approached the subject of rating in Section 2, we present our sample and methodology in Section 3, Section 4 will be devoted to the presentation of the results found, section 5 explains the causes of the market reaction to the rating announcement and we conclude in section6.

\section{Literature Review}

Reach literature test the effects of rating announcement to stock return and market reaction but results are mitigates. In developed market the majority of theses papers conclude the existence of an abnormal stock return markets to negative rating announcement (downgrades and negative review) but not to positive announcements (upgrades and positive reviews rating).

Literature in this area is rich, Dichev and Piotroski (2001) has primarily assessed the impact of ratings changes on the bond and stock markets, they finds that rating downgrades affect stock return and market reaction, but rating upgrades do not carry the same informative value.

According to Ederington and Goh (1998) most of the ratings downgrades are preceded by declines in firm income and analysts' forecasts. Goh and Ederington (1993) demonstrate that the rating announcement effect can be explained by the firm purpose. Announcements ratings driven by changes in the firm financial perspective, such as the possible income growth or debt increase, can have an impact on the stock market. Kliger and Sarig (2000) find that the information published by the rating anticipated by the market, has no effect on the firm value, they add that the stock price variation depends by unexpected changes rating. Elayan et al. (2003), analyzing the effect of rating announcement in New-Zealand rating, found abnormal stock return to positive announcements and suggested this reaction depend with corporate size. However, Abad-Romero and Robles-Fernandez (2006) in Spanish market: consider the absence of reaction to downgrades and negative announcement to upgrades. Koresh and Galil (2014) find that the market anticipates negative decision prior to the announcement date. Wengne et al (2015) examine the impact of rating events for the period 2004-2011. The results show that both downgrades and improvements ratings have an impact on the spread around announcement date.

To explain the effect of rating on stock prices, different hypothesis are presented: information content hypothesis, the signaling hypothesis and wealth redistribution hypothesis. Zaima and McCarthy (1988) analyzes information content hypothesis, they considers that the rating agencies provide additional information to the market about firm value. Ederington et al. (1989) suggest that ratings have greater information content than the market stock price since it includes private information collected by the rating agencies. Akhigbe et al. (1997) test signaling hypothesis, they consider that a rating change can be seen as a signal to the market about future profits, opportunity and cashes flows of firms. The hypothesis of wealth redistribution as defined by Zaima and McCarthy (1988), find the existence of a conflict of interest between bondholders and shareholders. Thus, lowering the rating reduces the bond price, which is expropriated from bondholders to shareholders and then increasing the share price. Romero and Fernandez (2006) indicate that ratings downgrades have no effect in the stock price but rating upgrade announcement generates significant impact on the Spanish market. They explain this behavior by the wealth redistribution hypothesis. Steiner and Heinke (2001) conclude that the factors explaining the market reaction is Downgrades into speculative class. Gropp and Richards (2001) analyzes rating change announcements on European banks. They attribute the effect on stock price to the Expected announcements hypothesis.

\section{Data and Empirical Methodology}

\subsection{Data}

Our database includes 67 rating announcements for the period between 1997 to, 2012, collected from Tunisian Stock Exchange (TSE), classified as 33 negative rating and 34 positive rating. In Tunisia there is only one rating company that evaluates Tunisian firms: "Maghreb Rating". We consider negative rating announcements in the cases of: downgrade note, negative review, downgrade and negative review; negative outlook revision or current rating confirmation. Furthermore, rating agencies, in most cases, confirm the latter notation. We considered any confirmation following degradation as a negative rating.

We classified the positive rating announcements to the following categories: upgrade; positive review; upgrade and positive review; positive outlook revision or current rating confirmation, ending a negative review.

\subsection{Econometric Model}

To test the impact of announcements ratings on the stock return, we follow Fama et al. (1969) procedures and terminology. We calculate daily abnormal returns and cumulative abnormal returns on an event period that begins twenty days before the announcement to twenty days after this day. 
In this study, we analyze the impact of ratings change announcements on the underlying issuer's share price. The estimation window, runs from 60 trading days before the announcement date, $t=0$, to 10 days before the announcement date. The event window runs from $t=-10$ to $t=+10$ (ten trading date after announcement date). To test the effect of ratings change announcements to the stock price, we calculate daily abnormal returns and cumulative abnormal returns during the event window.

To calculate abnormal returns, we use the market model and we calculate "normal "returns in the period before event ( sixty days before announcement to ten days before this day).

We use the market model to calculate the estimator: $\alpha_{i}, \beta_{i} e t \varepsilon_{i t}$ for each share, this model was estimated as follow:

$$
\begin{gathered}
R_{i t}=\alpha_{i}+\beta_{i} R_{m t}+\varepsilon_{i t} \\
\mathrm{E}\left(\varepsilon_{i t}\right)=0 \text { and } \operatorname{Var}\left(\varepsilon_{i t}\right)=\sigma \mathrm{i} 2
\end{gathered}
$$

$\mathrm{R}_{\mathrm{i}}$ and $\mathrm{R}_{\mathrm{m}}$ are the day returns of equity $\mathrm{i}$ and the market index.

We calculate the abnormal return on day $\mathrm{t}$ for share $\mathrm{i}\left(\mathrm{RA}_{\mathrm{it}}\right)$ as follow:

$$
R A_{i t}=R_{i t}-\hat{\alpha}_{i}-\hat{\beta}_{i} R_{m t} ; \quad \mathrm{i}=1 \ldots \mathrm{N}
$$

$\mathrm{RA}_{\mathrm{it}}$ : abnormal return on day $\mathrm{t}$ for share i. $\mathrm{t}=0$ is the announcement day.

$$
\begin{gathered}
E\left(R \hat{A}_{i t}\right)=R A_{i t}=\alpha_{t}+\beta_{t} R_{m t} \\
\text { and } V\left(R \hat{A}_{i t}\right)=\theta^{2} \sigma^{2}{ }_{i}
\end{gathered}
$$

To test the significance of the average residuals we uses student test "Tpar", the cross (Note 1) test, and signe test "T signe". We calculate the cumulative abnormal return CAR in the windows of $\mathrm{t}=-60$ to $\mathrm{t}=-10$.

\section{Empirical Result}

The abnormal returns around rating announcement are presented in Tables 1 to 4 . In Tables 1 and 2, the sample is classified in financials and non financials companies for negative (in Table 1) and positive rating (Table 2). We find that the stock price reaction to positive and negative rating announcement is more important and significant for financials companies. The market seems to be more interested in the rating announcement of Tunisians banks.

Table 3 present the abnormal return of stocks around announcement day of negative rating, the result is negative and statistically significant $(-0.48 \%)$ in the announcement day $(\mathrm{t}=0)$. We find significant abnormal return responses following downgrades rating announcements. We consider that downgrades generate stronger and more predictable results than upgrades. We conclude then, the negative and significant stock price reaction to negative rating announcement. The negative reaction persists and these downward trends continue six days after announcement day (graph $\left.{ }^{\circ} 1\right)$.

Rating downgrades announcement generate stronger and more predictable results than upgrades, which is in line with the majority of the financial literature dealing with rating changes.

Generally, the rating agency publishes the future prospects for long-term, and prior changing notification, decides to put firm under surveillance. This procedure helps investors to anticipate the rating degradation and react even before the public announcement, this explain the week market reaction to the negative rating announcement compared to other financial market.

The decision to revise the rating down is seen as a bad signal by investors. They are aware about the future firm performance and react, then, before the event date. Generally, when the information is made public, all investors are informed and the event loses its information relevance.

According to the table (3), the positive rating announcement does not influence the abnormal returns. This result corroborates those of Barron et al. (1997), Li et al. (2004) but contradicted those of Elayan et al. (2003) and Creighton et al (2006) who found a significant response after positive negative ratings announcements.

In Tunisian market, the positive rating announcement is not considered by investors as favourable information. Consequently, the upgrading rating may reflect a prudent corporate behaviour.

The negative reaction to downgrades rating leads us to search the factors that have caused this abnormal return. Various variables are presented to explain this reaction. 
Table 1. Cumulative abnormal return to downgrade rating announcement

\begin{tabular}{ccccccccc}
\hline & \multicolumn{3}{c}{ Sample 1: Financial Companies } & \multicolumn{3}{c}{ Sample 2: Non Financials Companies } \\
\hline Event period & $(0 ; 20)$ & $(-20 ; 20)$ & $(-1 ; 1)$ & $(-5 ; 5)$ & $(0 ; 20)$ & $(-20 ; 20)$ & $(-1 ; 1)$ & $(-5 ; 5)$ \\
Mean & 0.001408 & 0.002087 & -0.004447 & $8.54 \mathrm{E}-05$ & -0.000317 & -0.000734 & 0.000496 & -0.001194 \\
Mediam & 0.001769 & 0.001988 & 0.000589 & 0.000327 & 0.000326 & -0.000369 & -0.000580 & 0.000678 \\
STD & 0.004483 & 0.007304 & 0.028114 & 0.005712 & 0.003079 & 0.003365 & 0.015090 & 0.005908 \\
t-test & $\mathbf{2 . 4 8 6 5 2 2}$ & $\mathbf{2 . 0 9 2 2 4 1}$ & 0.528580 & 0.868522 & 0.676717 & 0.844356 & 0.054444 & 0.888038 \\
p-value & 0.0174 & 0.0432 & 0.6002 & 0.3906 & 0.5051 & 0.4068 & 0.9570 & 0.3833 \\
test wilcoxon & 2.907885 & 2.366883 & 1.257829 & 1.582430 & 0.256410 & 0.256410 & 0.358974 & 0.000000 \\
p-value & 0.0036 & 0.0179 & 0.2085 & 0.1136 & 0.7976 & 0.7976 & 0.7196 & 1.0000 \\
\hline
\end{tabular}

Table 2. Cumulative abnormal return to upgrade rating announcement

\begin{tabular}{ccccccccc}
\hline & \multicolumn{3}{c}{ Abnormal return: Financials companies } & \multicolumn{4}{c}{ Abnormal return: Non Financials companies } \\
\hline Event period & $(0 ; 20)$ & $(-20 ; 20)$ & $(-1 ; 1)$ & $(-5 ; 5)$ & $(0 ; 20)$ & $(-20 ; 20)$ & $(-1 ; 1)$ & $(-5 ; 5)$ \\
Mean & 0.000368 & 0.001455 & 0.009396 & -0.000809 & -0.000637 & 0.001854 & 0.008687 & -0.000398 \\
Mediam & 0.000178 & 0.000916 & 0.002406 & -0.000500 & -0.002015 & 0.001019 & $8.50 \mathrm{E}-06$ & $-3.55 \mathrm{E}-05$ \\
STD & 0.002840 & 0.002415 & 0.018271 & 0.005044 & 0.004359 & 0.004085 & 0.024031 & 0.007953 \\
t-test & 1.077323 & 1.423692 & $\mathbf{2 . 5 0 2 9 6 3}$ & 0.414889 & 0.041970 & 1.543193 & 1.317036 & 0.087082 \\
p-value & 0.2875 & 0.1619 & 0.0163 & 0.6803 & 0.9669 & 0.1370 & 0.2014 & 0.9314 \\
test wilcoxon & 1.279258 & 3.321377 & 2.288581 & 0.035209 & 1.010363 & 0.837158 & 0.144338 & 0.202073 \\
p-value & 0.2008 & 0.0009 & 0.0221 & 0.9719 & 0.3123 & 0.4025 & 0.8852 & 0.8399 \\
\hline
\end{tabular}

Table 3. Abnormal return around negative rating

\begin{tabular}{cccccc}
\hline & RAM & RAC & T1 student test & T2 rang test & T3 sign test \\
\cline { 2 - 6 } $\mathbf{- 5}$ & 0,000 & $-0,001$ & 0,235 & 0,870 & 0,360 \\
$\mathbf{- 4}$ & 0,001 & 0,000 & 0,612 & 0,174 & $-0,627$ \\
$\mathbf{- 3}$ & 0,002 & 0,003 & 0,960 & 1,914 & 0,997 \\
$\mathbf{- 2}$ & $-0,001$ & 0,001 & $-0,651$ & 0,174 & $-1,107$ \\
$\mathbf{- 1}$ & 0,002 & 0,003 & 0,764 & 0,870 & $-0,246$ \\
$\mathbf{0}$ & $-0,004 *$ & $-0,001$ & $-\mathbf{1 , 6 8 1}$ & $-\mathbf{0 . 5 2 2}$ & $\mathbf{- 1 , 5 7 5}$ \\
$\mathbf{1}$ & $-0,000$ & $-0,002$ & $-0,287$ & 0,174 & $-0,480$ \\
$\mathbf{2}$ & $-0,003$ & $-0,005$ & $-1,049$ & 0,522 & $-0,984$ \\
$\mathbf{3}$ & $-0,001$ & $-0,006$ & $-0,490$ & 0,870 & $-1,194$ \\
$\mathbf{4}$ & $-0,000$ & $-0,006$ & $-0,061$ & $-0,522$ & $-1,034$ \\
$\mathbf{5}$ & 0,001 & $-0,005$ & 0,625 & 1,218 & 0,590 \\
\hline
\end{tabular}

RAM: Average abnorma return, RAC: cumulative abnormal return, T1: student test; T2: rang test; T3: sign test. * significativity to $10 \%$; ** significativity to $5 \%$.

Table 4. Abnormal return around positive rating

\begin{tabular}{cccccc}
\hline & RAM & RAC & T1 student test & T2 rang test & T3sign test \\
\hline $\mathbf{- 5}$ & $-0,027$ & $-0,153$ & $-1,556$ & 0,000 & $-1,854$ \\
$\mathbf{- 4}$ & $-0,032$ & $-0,185$ & $-1,823$ & 0,000 & $-1,576$ \\
$\mathbf{- 3}$ & $-0,038$ & $-0,223$ & $-2,161$ & $-0,342$ & $-0,015$ \\
$\mathbf{- 2}$ & $-0,045$ & $-0,269$ & $-2,584$ & $-0,685$ & $-1,669$ \\
$\mathbf{- 1}$ & $-0,045$ & $-0,315$ & $-2,564$ & 0,000 & $-1,561$ \\
$\mathbf{0}$ & $-0,042$ & $-0,358$ & $-2,414$ & 1,371 & 1,391 \\
$\mathbf{1}$ & $-0,037$ & $-0,395$ & $-2,098$ & 1,028 & 0,973 \\
$\mathbf{2}$ & $-0,036$ & $-0,432$ & $-2,071$ & 1,371 & $-1,190$ \\
$\mathbf{3}$ & $-0,037$ & $-0,470$ & $-2,135$ & $-1,028$ & 0,108 \\
$\mathbf{4}$ & $-0,039$ & $-0,509$ & $-2,228$ & 1,028 & 0,046 \\
$\mathbf{5}$ & $-0,037$ & $-0,547$ & $-2,114$ & 1,028 & \\
\hline
\end{tabular}

RAM: Average abnorma return, RAC: cumulative abnormal return, T1: student test; T2: rang test; T3: sign test. 


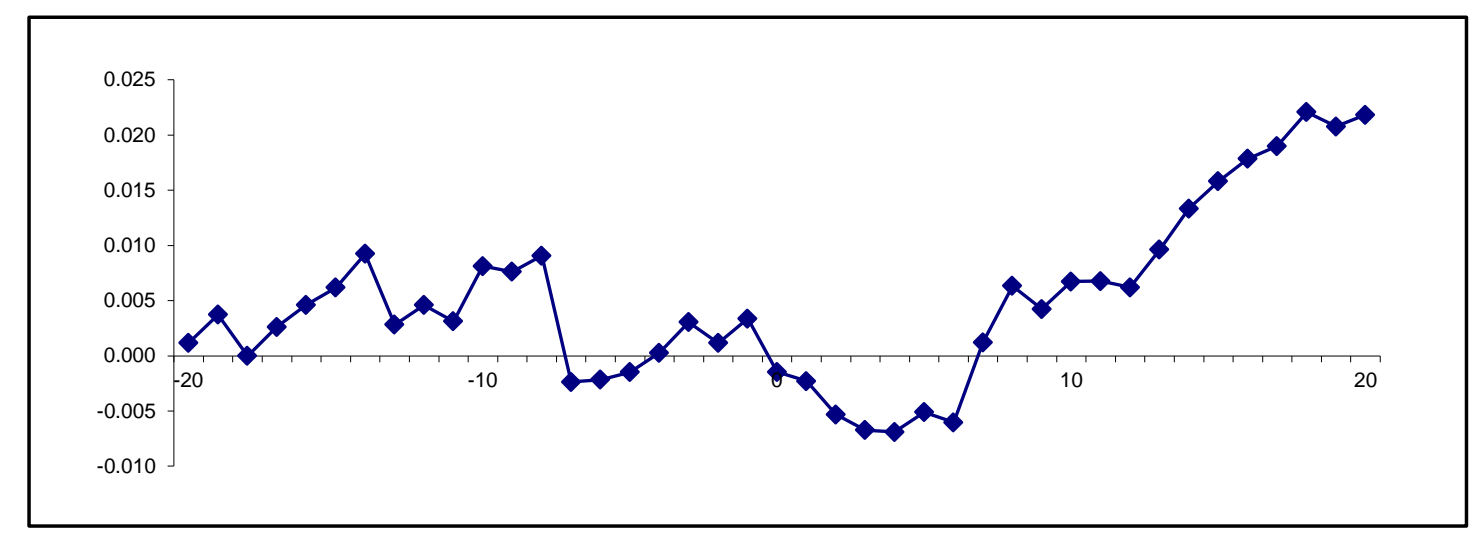

Figure 1. Stock price reaction to downgrade rating announcement

Figure 1 shows slightly positive pre -downgrade abnormal return, this reaction is followed by sharp negative reaction with sharp negative CARs following the rating downgrades announcements. Then, the pattern reverses again and we the abnormal return increase 7 days after announcement. The results from upgrade announcements were not statistically significant.

\section{Factors Explained Market Reaction}

Financial literature analyzing rating effect on stock market concludes that the size (total assets or total sales) of an issuer is an important factor explaining the market reaction. Others authors use total assets, leverage, profitability Return on assets ROA as independent variables. Since rating process between financial and non-financial firms is different, we utilize a dummy variable to distinguish them. FN is 1 if the rating changes apply to financials firms.

The effect on stock price at announcement day can also explained by frequency of downgrades, upgrades or if the firm is putted on surveillance. Make to negative surveillance transmit a signal to the market that the firm is in difficulty and prepare the downgrade. The market can then expect the future rating announcement. Hence we define MS as dummy variable equal to one if company is make to surveillance in the preceding rating and 0 if not.

We also test the hypothesis that equity markets will react more strongly to rating change announcements for firms with speculative grade ratings than to those with investment grade ratings. We consider DR dummy variable equal to 1 if the rating change is from speculative grade note (BB+/BB1 or lower) and 0 otherwise.

Book to market ration BTM measure the market performance at the announcement date of rating.

\begin{tabular}{lc}
\hline Independents variables & Expected Signs \\
\hline Size (Log VM) & $(+)$ \\
Leverage (ED) & $(-)$ \\
BTM & $(-)$ \\
Dowongrade (DR) & $(-)$ \\
Make on surveillance (MS) & $(-)$ \\
Financials companies (FN) & $(-)$ \\
\hline
\end{tabular}

To explain the market reaction to the negative announcement we use model follow:

$$
C A R_{i}=\beta_{0}+\beta_{1} \log (V M)_{i}+\beta_{2} E D_{i}+\beta_{3} B T M+\beta_{4} F N_{i}+\beta_{5} D R_{i}+\beta_{6} M S_{i}+\varepsilon_{i}
$$

In this model DR, $\mathrm{FN}$ et MS are binary's variables: $\mathrm{FN}=1$; if financial firm and 0 if not

$\mathrm{DR}=1$ if the rating note is low then (3B) and 0 if not, $\mathrm{MS}=1$ if the announcement proceeded by make on "negative surveillance".

VM: Firm size measured by log of the market value of equity; ED: firm leverage: the debt ratio, measured by total debt to book value of assets; BTM: is the book to market ratio. 
Table 5. Factors explained market reaction

\begin{tabular}{lllll}
\hline Variables & Coefficient & Std. Error & t-Statistic & Prob. \\
\hline C & -0.009452 & 0.005581 & -1.693590 & 0.1023 \\
VM & 0.002043 & 0.001566 & 1.304954 & 0.2033 \\
ED & $0.008940^{*}$ & 0.005245 & 1.704592 & 0.1002 \\
BTM & $\mathbf{- 0 . 0 0 0 3 7 5 * *}$ & $\mathbf{0 . 0 0 0 1 7 7}$ & $\mathbf{- 2 . 1 1 9 3 2 6}$ & $\mathbf{0 . 0 4 3 8}$ \\
DR & $-8.85 \mathrm{E}-12^{*}$ & $5.12 \mathrm{E}-12$ & -1.728938 & 0.0957 \\
MS & 0.000484 & 0.001606 & 0.301304 & 0.7656 \\
FN & -0.000268 & 0.001575 & -0.170269 & 0.8661 \\
\hline R-squared & 0.311753 & & & \\
Adjusted R-squared & 0.152927 & & & \\
\hline
\end{tabular}

$\mathrm{FN}=1$; if financial firm and 0 if not; $\mathrm{DR}=1$ if the notification is low then (3B) and 0 if not, MS=1 if the announcement is related to make on negative surveillance.VM: firm size measured by log of the market value, ED: firm leverage: the debt ratio , measured by total debt to book value of assets. (BTM) is the book to market ratio.

From the Table 5, we can conclude that the negative abnormal return around announcement can be explained by firm leverage, profitability and the level of downgrades. For rating downgrades, we confirm that rating downgrades for speculative grade firms have more severe price reactions than those for investment grade firms.

The results show that the debt ratio is a significant variable and that the relationship between debt ratio and the abnormal return is positive. This result confirms $\mathrm{Li}$ et al. (2004) and $\mathrm{Li}$ et al. (2006), who concluded that the debt ratio is correlated to the rating downgrade, expressing the deterioration of the company's financial structure.

Our result demonstrates that firm size is not significant and does not explain the market reaction to the announcement. This corroborates the results of $\mathrm{Li}$ et al. (2004) that find no effect of size on the abnormal return. Note also that the ratio Book to Market has a significant effect and can explain the market reaction at the announcement date.

We conclude also the negative impact of BTM on the abnormal return following announcements dates. Investors believe that the company's value is less than the book assets after negatives ratings announcements.

The level rating "downgrade" has a strong significance explaining the abnormal return, this variables is correlated to the level of lowest rating (below BBB). This results confirms those of Holthausen and Leftwich (1986), Jorion and Zhang (2005) who considers that the downgrade from one class to another are associated with significant negative abnormal return. Similarly, Creighton et al. (2006) show that in the case of the downgrade, ad effects are greater.

\section{Conclusion}

In this paper we tested the impact of rating changes on stock return in of Tunisian stock market. We applied the event study methodology and used two nonparametric tests and student test: test and sign rank test. Our results demonstrate that the market only react to degradations announcement of rating.

When the announcement is related to improvement notification, there is not an abnormal return around this date. We can conclude that the market was anticipated the event before his announcement, this information was used prior to its public divulgation.

To explain this market reaction to negative rating announcement, abnormal return is tested by different variables related to characteristics of firm, the operation and financial market. We have identified significant effects for the debt ratio, the ratio Book to Market and level of "downgrade".

These results corroborate studies Li et al. (2004), Holthausen and Leftwich (1986), Jorion and Zhang (2005) and Creighton et al. (2006). It appears that the announcement of such information on the situation of the company led to a negative impact on stock prices. This reaction occurs on the day of the announcement and continued several days later.

\section{References}

Abad, R., \& Robles, F. (2006). Risk and Return Around Bond Rating Changes: New Evidence From the Spanish Stock Market. Journal of Business Finance \& Accounting, 33(5-6), 885-908. http://dx.doi.org/10.1111/j.1468-5957.2006.00608.x

Akhigbe, A., Madura, J., \& Whyte, A. M. (1997). Intra-industry effects of bond rating adjustments. The Journal 
of Financial Research, 20(4), 545-561. http://dx.doi.org/10.1111/j.1475-6803.1997.tb00265.x

Andreas, W., Hans-Peter, B., \& Johannes, S. (2015). The impact of credit rating announcements on corporate CDS markets-Are intra-industry effects observable? Journal of Economics and Business, 78, 79-91. http://dx.doi.org/10.1016/j.jeconbus.2014.11.003

Barron, M., Clare, A., \& Thomas, S. (1997). The effect of bond rating changes and news ratings on UK stock returns. Journal of Business Finance \& Accounting, 24, 497-509. http://dx.doi.org/10.1111/1468-5957.00117

Creighton, A., Gower, L., \& Richards, A. (2006). The impact of rating changes in Australian financial markets. Pacific-Basin Finance $n^{\circ} 13$, juillet.

Dichev, \& Piotroski. (2001). The Long-Run Stock Returns Following Bond Ratings Changes. Journal of Finance, 56(1), 173-203. http://dx.doi.org/10.1111/0022-1082.00322

Ederington, L. H., \& Goh, J. C. (1998). Bond rating agencies and stock analysts: Who knows what when? Journal of Finance and Quantitative Analysis, 33(4), 569-585. http://dx.doi.org/10.2307/2331132

Elayan, F., Hsu, W., Meyer, \& Fall. (2003). The information content of credit rating announcements for share prices in a small market. Journal of Economics and Finance, 27(3), 337-356. http://dx.doi.org/10.1007/BF02761570

Fama, E. F., Fisher, L., Jensen, M. C., \& Roll, R. (1969). The adjustment of stock prices to new information. International Economic Review, 1-21. http://dx.doi.org/10.2307/2525569

Goh, J., \& Ederington, L. (1993). Is a bond rating downgrade bad news, good news, or no news for stockholders? Journal of Finance, 48. http://dx.doi.org/10.1111/j.1540-6261.1993.tb05139.x

Gropp, \& Richards. (2001). Rating Agency Actions and the Pricing of Debt and Equity of European Banks: What Can We Infer About Private Sector Monitoring of Bank Soundness? ECB Working Paper No. 76. http://dx.doi.org/10.1111/1468-0300.00064

Guttler, A., \& Behr, P. (2005). The stock market reaction to changes of unsolicited ratings. Working paper. http://dx.doi.org/10.2139/ssrn.724881

Kliger, D., \& Sarig, O. (2000). The information value of bond ratings. Journal of Finance, 55(6). http://dx.doi.org/10.1111/0022-1082.00311

Koresh, \& Galil. (2014). The informative value of credit rating announcements in small markets. Journal of Financial Stability, 14, 66-80. http://dx.doi.org/10.1016/j.jfs.2014.08.001

Lee-Hsien Pana et al. (2015). Reactions of Japanese markets to changes in credit ratings by global and local agencies. Journal of Banking \& Finance, 56-70.

Li, V., \& Charoenwong. (2004). Market reaction to credit rating announcements in the Irish stock market. Working paper.

Li, Q., Yang, J., Cheng, H., \& Young-Jae, C. (2005). The relationship between stock returns and volatility in international stock markets. Journal of Empirical Finance, 12, 650-665. http://dx.doi.org/10.1016/j.jempfin.2005.03.001

Li, J., Shin, Y., \& Moore, W. (2006). Reaction of Japanese market to changes in credit rating by global and local agencies. Journal of Banking \& Finance March, 30(3), 1007-1021. http://dx.doi.org/10.1016/j.jbankfin.2005.05.026

Matolcsy, Z. P., \& Lianto, T. (1995). The incremental information content of bond rating revisions: The Australian evidence. Journal of Banking and Finance, 19, 891-902. http://dx.doi.org/10.1016/0378-4266(94)00082-E

Miyajima, H., \& Yishay, Y. (2007). Japan's banking crisis: An event-study perspective. Journal of Banking \& Finance, 31, 2866-2885. http://dx.doi.org/10.1016/j.jbankfin.2007.03.006

Norden, L., \& Weber, M. (2004). Informational efficiency of credit default swap and stock markets: The impact of credit rating announcements. Journal of Banking \& Finance, 28, 2813-2843. http://dx.doi.org/10.1016/j.jbankfin.2004.06.011

Romero, \& Fernandez. (2006). Risk and returns around bond rating changes: New evidence from the Spanish stock market. Journal of Business \& Accounting, 33(5-6), 885-908. http://dx.doi.org/10.1111/j.1468-5957.2006.00608.x 
Steiner, M., \& Heinke, V. G. (2001). Event study concerning international bond price effects of credit rating actions. International Journal of Finance and Economics, 6, 139-157. http://dx.doi.org/10.1002/ijfe.148

Zaima, J. K., \& McCarthy, J. (1988). The impact of bond rating changes on common stocks and bonds: Tests of the wealth redistribution hypothesis. The Financial Review, 23(4). http://dx.doi.org/10.1111/j.1540-6288.1988.tb01283.x

\section{Note}

Note 1.

$\mathrm{T}$ cross $=\mathrm{RAM} / \mathrm{SRAMi}$

$S R A M_{t}=\sqrt{\frac{1}{N-1}} \sum_{i=1}^{N}\left(R A_{i, t}-R A M_{t}\right)^{2}$

\section{Copyrights}

Copyright for this article is retained by the author(s), with first publication rights granted to the journal.

This is an open-access article distributed under the terms and conditions of the Creative Commons Attribution license (http://creativecommons.org/licenses/by/3.0/). 